\title{
IMPROVING THE EFFECTIVENESS OF THE SPECIAL AND DIFFERENTIAL TREATMENT OF THE WORLD TRADE ORGANIZATION
}

\author{
RESEARCH PAPER \\ LAWS 582: MASTERS LEGAL WRITING \\ FITRIA ANINDHITA H. WIBOWO
}

FACULTY OF LAW

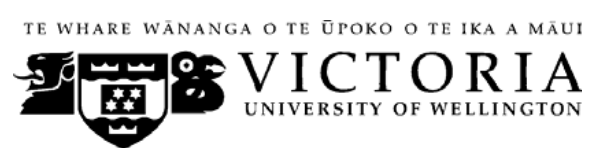

2015

The text of this paper (excluding abstract, table of contents, footnotes, appendix, and bibliography) comprises 11999 words. 


\section{Contents}

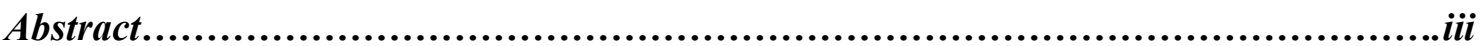

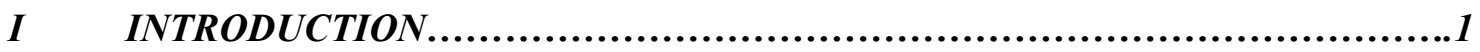

A $\quad$ Overview.................................................................

B Development of the Special and Differential Treatment......................3

C Purpose and Function of the Special and Differential Treatment in the

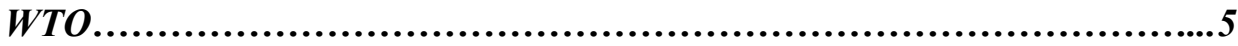

D Negotiations to Improve Special and Differential Treatment...................7

II CHALLENGES IN THE IMPLEMENTATION OF SPECIAL AND

DIFFERENTIAL TREATMENT ..........................................

A The Concept of Development.............................................9

B The "Developing Country" Issue .......................................12

C The Rules on Flexibility.................................................15

D The Legal Status of Special and Differential Treatment.....................18

III RELATIONSHIP BETWEEN THE DISPUTE SETTLEMENT SYSTEM AND

SPECIAL AND DIFFERENTIAL TREATMENT............................20

A Special and Differential Treatment in the DSU.........................20

B Problems for Developing Countries...................................21

C Interpretation of Provisions.........................................23

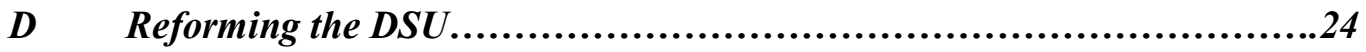

IV Making Special and Differential Treatment More Effective, Precise, and

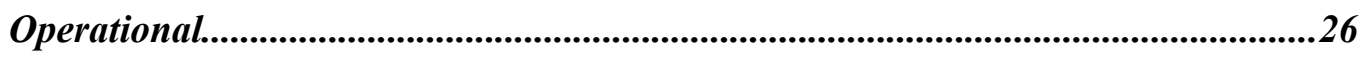

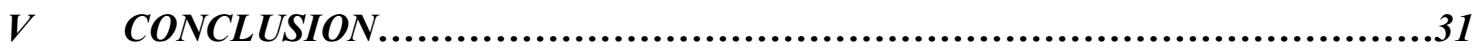

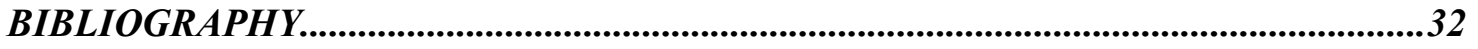




\section{Abstract}

This paper deals with the subject of Special and Differential Treatment (SDT) of the World Trade Organization (WTO), a special right that allows developing countries preferential treatment by other member countries, particularly developed countries. The paper more specifically discusses the ineffectiveness of the SDT owing to its structure and formulation, and explores the factors that have caused such ineffectiveness. It touches upon the provisions and the ways in which they are formulated and implemented, which deemed to have lead to the ineffectiveness. An observation of the way that negotiations are conducted and the underlying interests that direct those negotiations also contribute to the slow progress of introducing changes to the provisions. Furthermore, this paper analyses and identifies steps that may be taken to improve the concept, formulation, and implementation of SDT, inter alia through amendments of the provisions and conduct of negotiations. The paper also looks at several dispute cases which highlight the ineffectiveness of the existing provisions in advancing the interests of developing countries in particular and in fulfilling its purpose in general.

\section{Subjects and topics}

WTO

Special and Differential Treatment

WTO provisions on SDT 


\section{Introduction}

This paper discusses the improvement that can be made to enhance the effectiveness of the Special and Differential Treatment (SDT) needed to attain a balance in trade benefits obtained by developed and developing country members through the WTO system. In doing so, this paper highlights the development of the SDT during the Uruguay Round of the WTO and the factors that necessitated a change in its old formula and implementation, which continues to require further improvements today. The paper attempts to identify the elements in the implementation of SDT which have been deemed insufficient to further advance the interests and balance sought by developing countries and explores the ways in which improvements can be made, including through the formulation and interpretation of SDT provisions.

\section{A Overview}

Since its inception, the WTO has recognized the importance of facilitating developing and least-developed countries (LDCs) participation in the multilateral trading system. This recognition stems from the realization that globalization and trade liberalization is necessary for growth and progress, but that they also create winners and losers within the system. Depending on market size, level of development and the country's capacity in utilizing the WTO system, it can either reap significant rewards or sustain injuries to its industries. The WTO attempts to minimize the inequality between countries within the system by providing preferential treatment to the less developed countries with the aim of distributing the benefits more equally. ${ }^{1} \mathrm{SDT}$ is a tool used by the WTO for this particular purpose.

One could opine that the central value of the WTO is trade liberalization, from which notions of greater development, increased economic growth and income, higher living standards, and less poverty is expected to transpire. But the challenge for many developing countries is how to attain the needed skills to excel and to take advantage of trade liberalization, in areas such as policy development, producing higher quality goods and services, adjustment to increased competition, and learning to use resources more effectively. ${ }^{2}$ By providing SDT in its agreements, the WTO intends to balance the role and

\footnotetext{
${ }^{1}$ Ross P. Buckley ed The WTO and the Doha Round: The Changing Face of World Trade (Kluwer Law International, The Hague, 2003) at 4.

${ }^{2}$ Buckley, above n 1, at 9 .
} 
capacity of its member countries. The SDT comprises means to produce the desired outcomes by providing better and fairer access to developing member countries and LDCs.

SDT comprises of special provisions that allow developing countries to be treated more favourably than and particularly by developed member countries. These provisions are an integral part of the WTO agreements and as such are obligatory upon member countries. The basis for SDT can be found in the Agreement Establishing the World Trade Organization which refers to sustainable economic development as one of WTO's main objectives. ${ }^{3}$ The General Agreement on Tariffs and Trade (GATT) consists of provisions on the concept of non-reciprocal preferential treatment for developing countries that allows developing countries to give less than reciprocal treatment to developed countries. ${ }^{4}$ The Enabling Clause is the basis for the Generalized System of Preferences (GSP), which has been practiced for many years to extend preferential treatment, often in the form of low tariffs to products originating from developing countries. ${ }^{5}$ GSP is implemented at bilateral level, where a developed country grants preferential treatment to a developing country based on selfdesignated and unilaterally imposed standards. The General Agreement on Trade in Services (GATS) gives attention to the needs of developing countries to advance their services sector and allows them to restrict trade in services for reasons of balance-of-payment difficulties. ${ }^{6}$ The Agreement on Trade-Related Aspects of Intellectual Property Rights (TRIPS) gives LDCs the right to longer implementation period on all the provisions and the possibility of technical assistance. ${ }^{7}$

The provisions contained in the WTO agreements are in part mandatory or binding upon member countries, and also non-mandatory, meaning the only obligation it entails is the consideration of developing countries' interests. SDT gives special rights to developing countries that allow them longer time periods and exceptions in implementing agreements and commitments, to receive technical assistance, preferences and flexibility in WTO disciplines and procedures, specific commitments in services, and consideration of interests by developed countries. ${ }^{8}$ On the other hand it creates an obligation for developed country members to consider and implement measures that would increase trading opportunities for

\footnotetext{
${ }^{3}$ WTO Secretariat "Special and differential treatment provisions" < www.wto.org $>$.

${ }^{4}$ Above $\mathrm{n} 3$.

${ }^{5}$ Above $\mathrm{n} 3$.

${ }^{6}$ Above $\mathrm{n} 3$.

7 Above $n 3$.

${ }^{8}$ John Whalley "Special and Differential Treatment in the Millennium Round" (1999) CSGR Working Paper No. 30/99<www.dspace.africaportal.org>, at 13 .
} 
developing countries, to safeguard developing countries' trade interests, and to provide technical assistance.

At a glance SDT would appear like a reasonable solution to balance the distribution of benefits among member countries, but it is not a concept without flaws, particularly in its implementation. SDT was agreed through compromise, much like any other provisions negotiated in the WTO. This compromise resulted in the numerous yet inadequate SDT provisions found across the WTO agreements, which led to SDT being ineffective in producing the desired outcomes promised by trade liberalization. This paper explores the different factors which may have led to such ineffectiveness and the possible elements that can be strengthened to improve the effectiveness of SDT.

\section{B Development of the Special and Differential Treatment}

SDT is a concept that dates back to the GATT. It was created to establish a more equitable system that enables developing countries to foster and protect their domestic industries and compete on a more equal footing with their developed counterparts. ${ }^{9}$ Developing countries had felt that it was not fair to subject them to the same rules and obligations as developed countries when their trade capacity and competitiveness were not at par. They sought to have the rules relaxed by arguing that the very foundation of the GATT which is rules-based and non-discriminatory ${ }^{10}$ has led to inequality due to its indifference to lack of development. As a result changes were made to the GATT framework to include SDT for developing countries, namely to allow non-implementation of commitments and restrictive measures under certain conditions, exemptions from export subsidies prohibition, the use of tariff protection, encouraging developed countries to increase trade opportunities including through the GSP scheme and the Protocol for Trade Negotiations. ${ }^{11}$

Furthermore, the Parties adopted the "Enabling Clause" which cemented SDT as part of the GATT legal system. It was considered to have done little to increase the participation of developing countries and to have not been successful in attaining its objectives, partly because it prompted developing countries to adopt high tariffs to protect their domestic industries and because LDCs were not granted adequate preferential access to developed

\footnotetext{
9 Edwini Kessie "The Legal Status of Special and Differential Treatment" in WTO Law and Developing Countries (Cambridge University Press, New York, 2007), at 17.

${ }^{10}$ Above $\mathrm{n} 9$, at 16.

${ }^{11}$ Above n 9, at 18.
} 
countries' markets. ${ }^{12}$ Allowing developing countries to derogate from the fundamental obligations of the GATT and providing preferential treatment without greater recognition of the root causes of their constraints and addressing the reasons for their ineffective participation was not enough. The Enabling Cause was deemed ineffective in addressing their limited capacity.

During the Uruguay Round of negotiations, developing countries opted for greater market access in place of preferential treatment, as well as an inclination to be governed by the WTO agreements without the preferences available to them previously. ${ }^{13}$ Even though it seems as though the concept of SDT has been diluted under the WTO, it gave greater consideration to more elements necessary for increasing trade for developing countries. These elements are reflected in the five different groups of provision found across the WTO agreements, namely, provisions aimed at increasing trade opportunities, provisions to safeguard the interests of developing countries, provisions allowing developing countries to assume lesser obligations, provisions relating to transitional time periods, and provisions relating to technical assistance. ${ }^{14} \mathrm{~A}$ major portion of the provisions found in the agreements deal with safeguarding the interests of developing countries, followed by flexibility, increase of trade opportunities and technical assistance. ${ }^{15}$

The new SDT provisions can be categorized as mandatory for those containing the term "shall" and non-mandatory for those containing the word "should". ${ }^{16}$ Fritz explains that "however, "shall" formulations can be limited in their binding character since they may allow considerable flexibility in their implementation, thus not necessarily effective". ${ }^{17}$ Furthermore, in determining the effectiveness of a provision one would need to consider "the difference between "obligations of result" which decide a certain result and "obligations of conduct" which leaves open the means by which result is being achieved and do not set a concrete objective at all". ${ }^{18}$ Admittedly there is a problem in the binding nature of the provisions which pose a challenge to the effectiveness of SDT since the very beginning

\footnotetext{
${ }^{12}$ Kessie, above n 9, at 19.

13 Above $\mathrm{n}$ 9, at 21.

${ }^{14}$ Above $n$ 9, at 23.

15 Thomas Fritz "Special and Differential Treatment for Developing Countries" (2005) Global Issues Paper No. $18<$ www.thomas-fritz.org>, at 14 .

${ }^{16}$ Above $\mathrm{n} 15$, at 13 .

17 Above $\mathrm{n} 15$, at 13 .

${ }^{18}$ Above $\mathrm{n} 15$, at 13 .
} 


\section{Purpose and Function of the Special and Differential Treatment in the WTO}

The Marrakesh Agreement Establishing the WTO recognizes that trade should be conducted by giving attention to the different levels of economic development of member countries. Thus, the WTO recognizes that there is an essential link between trade and development. The launching of the Doha Round of Negotiations in 2001, which put development at the heart of the WTO, was aimed at improving the role and participation of developing countries and LDCs in the multilateral trading system. The Doha Development Agenda (DDA) in particular intends to strengthen and improve the WTO provisions by giving special attention to developing countries' and LDCs' needs and interests. The SDT as one such provision grants special rights to developing countries and LDCs in order to facilitate their participation and enables the attainment of balance in the system, which would ultimately contribute to their development. Through such provisions, the WTO allows "smaller countries the opportunity to protect their trade interests, shelters from discrimination, increases market access, and provides special treatment". ${ }^{19}$

Essentially, "SDT allows differentiated treatment for developing countries within the WTO system by justifying deviation from the most-favoured nation (MFN) obligation". ${ }^{20}$ SDT is non-reciprocal because it is provided by developed countries as supposedly "the haves" to developing countries who are the "haves not". In this sense it is a unilateral action where the principle of reciprocity does not apply. ${ }^{21}$ SDT provides special rights for developing countries and LDCs to facilitate their participation in the multilateral trading system by allowing them better access to markets; flexibility on obligations; safeguard of interests by other member states; transitional periods in implementing agreements; and technical assistance. ${ }^{22}$ Overall, the provisions can be seen as an achievement, particularly by developing countries, in shaping the current construct of the WTO. There are a total of 148 SDT provisions contained across the WTO agreements which as mentioned above can be grouped as follows ${ }^{23}$ :

\footnotetext{
${ }^{19}$ Ann Capling "The Multilateral Trading System at Risk? Three Challenges to the World Trade Organizations" in Buckley, above n 1, at 38.

${ }^{20}$ Akiko Yanai "Rethinking Special and Differential Treatment in the WTO" (2013) IDE Discussion Paper 435, at 1 .

${ }^{21}$ Above $\mathrm{n} 20$, at 2 .

${ }^{22}$ Amin Alavi Legalization of Development in the WTO: Between Law and Politics (Kluwer Law International, Aphen aan den Rijn, 2009), at 84.

${ }^{23}$ Yanai, above n 20, at 3.
} 
1. Provisions aimed at increasing trade opportunities: these provisions encourage member countries to adopt measures and grant preferences that would increase trade opportunities for developing countries and LDCs.

2. Provisions to safeguard the interests of developing countries: include actions to be taken or avoided by member countries to safeguard the interests of developing countries, some are formulated as obligations while some are not legally enforceable.

3. Provisions allowing developing countries to assume lesser obligations: relate to flexibility in implementing obligations, which includes exemptions, reduced level of commitments, and simplification of procedures.

4. Provisions relating to transitional time periods: relate to exceptions that allow developing countries longer transitional periods to implement their obligations.

5. Provisions relating to technical assistance: these provisions can be found in specific agreements and require developed country members or the WTO Secretariat to enable developing countries to comply with their WTO obligations.

6. Provisions relating to LDC members: include all previous provisions and exclusive to LDCs.

Despite the seemingly comprehensive type of provisions, the very challenge of SDT lies in its implementation. The provisions, however formulated to suit the needs of developing countries, are a product of political compromise. As such, their functioning has not lived up to expectation. There appears to be uncertainty in the legal status of these provisions, which can be perceived from the language in which they are formulated, that is as legally-enforceable obligations or best-endeavour clauses. Consequently, one of the aims of the Doha Round is to make those provisions more "precise, effective, and operational", for them to truly contribute to the development of developing members. 13 years on since the launch of the Doha Round however, members have yet to agree and finalize the amendments to the relevant SDT provisions contained in the WTO Agreements.

\section{Negotiations to Improve Special and Differential Treatment}

Member countries' effort to make the currently existing provisions more precise, effective, and operational has fallen short of clearly identifying what makes them ineffective 
and converging views on the means to improve them. The most obvious reason for this is the diverging interests and conditions, not only between developed and developing countries and LDCs, but also among developing countries. Because the on-going negotiation on SDT has taken longer than envisaged, they fail to reflect the current reality and fall behind developments on the ground. Member countries are showing symptoms of frustration and apathy which many fear could lead to a failure in securing the amendments, and in turn could potentially harm the entire round of negotiations.

The negotiation has been ongoing since 2001 and has yet to reach conclusion. The varying interests of member countries which lead to diverging positions on SDT continue to play a significant role in the impasse of the Round. Despite many elaborations by experts on possible ways forward and the identification of potential solutions, member countries continue to negotiate as usual in that they continue to be driven by their respective political agendas. In analysing the proposals for amendment, which are mostly formulated during the first half of the Doha Round, it seems that the context would no longer be suitable or apply to a number of developing countries or LDCs who have progressed further in their development. On further analysis, despite the fact that the Doha Round is supposed to be a development round, member countries seem to have lost their grasp on the actual concept of development and how to best achieve it through trade.

Over the past 13 years, member countries have reviewed the relevant provisions with a view to amending them. Proposals for amendments include "clarification of the principles, the purpose, and the coverage of SDT, where requests of developing countries are focused on attaching importance of SDT as an integral part of the multilateral trading system and to establish a legally-binding SDT regime". ${ }^{24}$ Developing countries are of the view that trade liberalization should be mutually beneficial and that it should lead to sustainable development as well as improved prosperity, so that the strengthening of the SDT provisions is a prerequisite to securing profits. ${ }^{25}$ Another important aspect of developing countries' demands is for a mechanism to monitor (the Monitoring Mechanism) the implementation of SDT across the agreements and to make recommendations with regard to improving effectiveness, including the need for new negotiations.

${ }^{24}$ Yanai, above $\mathrm{n} 20$, at 4.

${ }^{25}$ Above n 20, at 4. 
The negotiation for the improvement of SDT is carried out in the Committee on Trade and Development (CTD) in Special Session (SS). Currently there are 88 proposals from developing countries and LDCs, which are mostly initiated by the African Group and the group of LDCs. These proposals "identify parts of an agreement and suggest new wording to introduce new special and differential treatment provisions for developing countries or to strengthen existing ones". ${ }^{26}$ They can be subdivided into three categories as such: 1) Category I containing 38 proposals that are deemed more likely to be accepted with minor changes; 2) Category II which consists of 38 proposals which are forwarded and discussed in the relevant WTO bodies; and 3) Category III which includes 12 proposals requiring major drafting. ${ }^{27}$ These proposals are also referred to as Agreement-Specific Proposals (ASP).

To date only the Monitoring Mechanism has been agreed upon by member countries. The mechanism allows member countries to analyse and review every aspect of SDT implementation and make recommendations for improvement through re-negotiations and provides an opportunity for resolving challenges faced by developing countries in utilizing SDT provisions. ${ }^{28}$ The road to reaching a final agreement on Monitoring Mechanism was a tough one with member countries divided on what they perceive was the function of the mechanism. Developing countries wanted it be an all-encompassing mechanism with a mandate to oversee and enforce the implementation of SDT provisions as well as initiate discussions on the improvement of ineffective provisions. Developed countries were of the view that this was too extensive and that it would overlap with the functions of the committees.

Work on the three categories remains ongoing with member countries focusing on updating the proposals to better reflect the developments which have taken place. The Chairman of the CTD-SS suggested that member countries develop a clear road map with tangible substance and work persistently to achieve an agreeable result given the complex nature of the issues and to avoid further impeding progress. ${ }^{29}$ Part of the difficulties lies in that some member countries have agreed on the proposed changes while others insist on going over the discussions again, thus reinventing the wheel. This scenario for example is often found in the negotiation on the 28 ASP already agreed in principle during the Cancun

${ }^{26}$ WTO Secretariat "Cancún WTO Ministerial 2003: Briefing Notes on Special and Differential Treatment: Grappling with 88 proposals" $<$ www.wto.org $>$.

27 Above $\mathrm{n} 25$.

${ }^{28}$ Committee on Trade and Development "Note on the meeting of 25 March 2014" (2014) TN/CTD/M/48, at 1.

29 Above n 28, at 3. 
Ministerial Meeting in 2003, which include among other provisions regarding import licensing procedures, rules of origin, technical assistance, technology transfer, technical cooperation, dispute settlement procedures, and procedures for balance-of-payment consultations, in various agreements. When faced with this kind of difficult situation member countries often recoil from going further into the discussion.

\section{Challenges in the Implementation of Special and Differential Treatment}

\section{A The Concept of Development}

We can all agree that development can benefit from trade and that trade liberalization is one of the important tools for development to flourish. Yet, the concept of development may be viewed differently from the perspective of developing and developed countries. ${ }^{30}$ There is no single method of defining development, and most certainly no one agreed approach to attaining it. The different views and approach to development, what it is, means of achieving it, or its end-goals all factor in to the debate of effectively utilizing SDT. Without a collective understanding of development, the discussion on how to best make use of SDT may continue to drag on and marked by the variance of views and positions that have long hindered convergence.

To many developing countries, free trade is necessary but not always sufficient for achieving the desired level and nature of development. Socio-economic development is to accompany and balance liberalization at all stages. When formulating trade rules at the multilateral level, assumptions are often made as to what constitutes development and a tendency toward generalization is made in identifying the characteristics, needs, and treatment of developing countries. ${ }^{31}$ The rules which are to be implemented at the national level through policies may not have fully considered the real situations faced by developing countries, hence their implementation may not be as profitable as intended. The capacity to formulate policies which comply with the obligations and at the same time suit the local condition would reflect a country's level and need of development.

Although development was given higher importance and focus in the Uruguay Round to facilitate the integration of developing countries into the multilateral trading system, the

\footnotetext{
${ }^{30}$ Constantine Michalopoulos "The role of special and differential treatment for developing countries in GATT and the World Trade Organization" (1999) World Bank Policy Research Working Paper, at 2.

${ }^{31}$ Sheila Page "The Evolution of Special and Differential Treatment in the Multilateral Trading System" (2004) International Centre for Trade and Sustainable Development, at 4.
} 
question remains whether the SDT afforded to them resulted in policies or outcomes that are more suitable for development. ${ }^{32}$ Michalopoulos sums up the question regarding SDT and development as such:

\begin{abstract}
The key issues that need to be addressed in the context of the special provisions... are the commitments for preferential market access and treatment offered by developed countries meaningful relative to the constraints these countries face in integrating in the world trading system? Is the international technical assistance in support of these countries adequate and effective? And does the flexibility offered to these countries in meeting their WTO commitments contribute to their long term trade and development objectives ? $^{33}$
\end{abstract}

Furthermore, successful outcomes depend on the country's ability to utilize those provisions to their advantage. Many are still lacking such ability because they have not been able to map out their own strengths and weaknesses, let alone formulate policies which corresponds to those characteristics. Hence, SDT provisions should be formulated based on a clear understanding of the links between trade and development and the real constraints faced by developing countries. ${ }^{34}$

One frequently criticized element of SDT is the GSP scheme, which on the face of it is the preferential treatment of products originating from developing countries and more often LDCs. GSP is not provided based on the MFN principle, so the recipient is selected unilaterally by the providing country, often at their own terms and conditions. Thus, the GSP scheme is not unconditional or less than reciprocal and is often given to developing countries or LDCs from whom the provider can also benefit or receive a concession in return. Moreover, because it is the provider's discretion to decide who benefits from the GSP scheme, non-economic criteria, such as human rights development, democratization, and environmental standards, have become conditions for providing it. ${ }^{35}$ Another problem that has arisen is that the preferential treatment given to one trading partner can harm the export of another. This has been demonstrated by India, who filed a complaint to the Dispute Settlement Body regarding the action of the European Communities (EC) to extend lower tariff duties to Pakistan on textiles due to its compliance to environmental standards set by the EC (EC-Conditions for the Granting of Tariff Preferences to Developing Countries,

\footnotetext{
32 Page, above n 31, at 20.

${ }^{33}$ Michalopoulos, above n 30, at 23.

${ }^{34}$ Above $n$ 30, at 34 .

35 Norma Breda dos Santos, Roge Ârio Farias and Raphael Cunha "Generalized System of Preferences in General Agreement on Tariffs and Trade/World Trade Organization: History and Current Issues" (2005) Journal of World Trade 39(4) <www.academia.edu>, at 657.
} 
Request for the Establishment of a Panel by India, WT/DS246/4 (9 December 2002). ${ }^{36}$ The Appellate Body emphasized that the GSP scheme is not non-discriminatory and does not require the provider to extend similar treatment to other trading partners, thus reaffirming the non-MFN character of GSP and that preferential treatments may be given based on the exchange of concessions. ${ }^{37}$

The idea that trade liberalization leads to faster development also cannot be applied to everyone. The one-size-fits-all approach to SDT provisions seems to be inadequate given the diversity of developing countries and the complexities attached to their individual characteristics. It may also be responsible for the "existing "pretend" culture at the WTO where developing countries pretend that they should all be treated the same while developed countries pretend to have provided meaningful SDT". ${ }^{38}$ So more importantly SDT should focus on providing more meaningful provisions and appropriate instruments which can strengthen domestic capacity and provide safety nets to cushion against adjustment costs. ${ }^{39}$ SDT provisions need to recognize and address the different situations of developing countries as well as the real impacts of trade, whether positive or negative, on development.

Technical assistance is also an important aspect of SDT implemented through agreements such as TRIPS, GATS, TBT (Technical Barriers to Trade), and SPS (Sanitary and Phytosanitary), particularly to assist developing countries to enable compliance and offset the cost of implementation. ${ }^{40}$ Even as such, technical assistance has been deemed less than effective in increasing the participation of developing countries in the multilateral trading system because it is not tailored specifically to the needs and condition of each developing country that receives it. ${ }^{41}$ One of the forums where technical assistance is regularly addressed and reported is in the Aid-for-Trade session of the CTD. It has been reiterated many times in that forum that technical assistance need to take into account the situation of the recipient country rather than the donor's ideal notion of what could advance the capacity and development of the recipient. The technical assistance programmes provided by the Secretariat are also designed to be general in nature and requires that participants have more or less the same prior knowledge of the subject. Participants in many countries may not all

\footnotetext{
${ }^{36}$ dos Santos, above n 35, at 660 .

${ }^{37}$ Above n 35, at 660.

${ }^{38}$ Page, above n 31, at 33.

${ }^{39}$ Above n 31, at 29.

${ }^{40}$ Fritz, above n 15, at 24.

${ }^{41}$ Above $\mathrm{n} \mathrm{15}$, at 24.
} 
have the same prior knowledge, have language barrier problems, or require more specialized programmes.

Another important question to tackle is whether the provisions have been effective in levelling out the playing field between developed and developing countries. Have the provisions directly or indirectly resulted in the increased capacity which enables developing countries to balance the role that developed countries play in the multilateral trading system and catch up with their progress. Developments have many facets and forms which need to be taken into account when dealing with different countries, so the simplistic view that SDT is potentially beneficial to every developing country would be incorrect. A country that has gained expertise in utilizing flexibilities and thereby attracting more markets to it because of lower costs, may actually be directing those markets away from other developing countries who are still less efficient and thereby reducing its trade opportunities. Therefore SDT, even in its most opportunity-providing form needs to carefully consider the different realities faced by developing countries.

\section{B The "Developing Country" Issue}

One of the major problems which have been identified with regard to the implementation of SDT provisions is the status of developing countries in the WTO. It is widely recognized that this category applies to a wide range of countries who in reality may be disparate in terms of level of development. The definition of developing country and who belongs to this category in the WTO follows the United Nations system, hence the WTO does not have its own standard for categorizing these countries. All countries who fall under this group are equally entitled to SDT regardless of their characteristics, capacity, size, or GDP. Deeper flexibilities are only given to the group of LDCs.

As discussed previously, the success of utilizing SDT depends on capacity, which in relation to level of development should ideally differentiate the flexibilities afforded. The large number of developing countries in the WTO also means that they have various needs and interests which means that the general nature of SDT cannot cater to all their aspirations. It may be because the non-discrimination principle, which is a core of the WTO, also applies to SDT so that all developing countries are to be treated alike and given the same flexibility and preference by the other member countries. But it leads to the question of whether the application of non-discrimination is appropriate when it comes to flexibility, notwithstanding 
the fact they already exist for GSP schemes, and whether a balance can be attained by applying them universally to all developing countries.

Additionally we need to ask whether indiscriminate provisions have resulted in similar outcomes across developing countries, whether they are equally effective and beneficial for everyone. How much increase in capacity or economic growth is experienced by different countries as a result of the same provisions being implemented by them? Developing countries inherently have different resource availability and capacity to which they tailor their trade agenda and priorities. According to that agenda and priorities each may require a distinct flexibility or assistance. Therefore not all flexibility is applicable or adequate for every developing country.

The different characteristics and interests among developing countries have also contributed to the complexity in negotiations. Although essentially developing countries intend to improve SDT to better facilitate their trade, it is not uncommon for them to echo different concerns and voice different positions in the negotiations. It is also not uncommon for developing countries not to support the proposals of other developing countries when they feel that it does not represent their interests or can potentially harm them. Furthermore, politically every member country supports the streamlining of accession procedures for developing countries and LDCs into the WTO, but in reality some still require significant concessions to balance the access to markets which they will have to share with or provide to the new WTO member. The problem in reaching consensus is often times prompted from within the group itself because developing countries cannot find a common position. The negotiations have demonstrated how divided developing countries can be in the pursuit of their interests. Although generally developing countries support one another, they also form alliances or groupings with other countries of similar interests or those who can better shape and influence the negotiations based on their interests. ${ }^{42}$

Trade liberalization attempts to provide everyone with the same opportunity to participate in world trade and have access to markets. Opening up markets to more countries means creating more competition, both for domestic producers and among foreign producers, which can be a positive or negative thing, depending on resources and capacity. Opening up markets to developing country producers without differentiating among them creates competition which not all developing countries have the capacity to overcome. Developing

${ }^{42}$ Alavi, above n 22, at 87. 
countries with moderate capacity such as Chad, Myanmar, or Sri Lanka will experience considerable setbacks if forced to compete with more advanced developing countries such as Singapore, India, or South Africa. So another important element to reconsider is not only to afford a level playing field with developed countries, but also to enable them to compete with fellow developing countries. The recognition that there are always winners and losers in trade liberalization needs to go beyond the traditional notion of developing counties and figure out a method of providing SDT only to those who need it, which would not logically include emerging economies. It may be a complicated task, but unless it is done, SDT would not have served much purpose to assist the most disadvantaged.

The facts suggest that some more advanced developing countries have no difficulties competing with developed countries so they may not require assistance in penetrating foreign markets. ${ }^{43}$ Furthermore, there is a risk in providing SDT to more competitive developing countries that it may be utilized to maintain protectionist policies to fend off foreign competition and advance domestic products. These protectionist measures could do well to establish dominance of domestic products at home but at the expense of consumers due to higher prices. Often times, lack of competition domestically also leads to underdevelopment of sectors because there is no stimulus for improvement. That is not to say that a lot of countries do not still need to maintain high tariffs and subsidies, but there are chances that the permissiveness of WTO SDT could lead to "distortions in domestic resource allocation, encourage rent seeking and waste and adversely affect growth in productivity and sustainable development". 44

Providing meaningful SDT in terms of market access or flexibilities must take into account the capacity to export or compete in international markets, because they vary greatly among developing countries. This is especially important if we are to afford real SDT that provide appropriate instruments to countries who most need it. ${ }^{45}$ The constraints faced by various developing countries must be understood to mean that each require different treatment, hence it would be necessary to differentiate between developing countries. Differentiation would sub-categorize developing countries according to level of development

\footnotetext{
${ }^{43}$ Michalopoulos, above n 30, at 25.

${ }^{44}$ Above $n$ 30, at 28.

${ }^{45}$ Above n 30, at 34.
} 
and capacity and provide a standard for selecting who is eligible for what. At the same time it will render the form and content of SDT more focused and targeted. ${ }^{46}$

Member countries will have to go beyond the existing modalities and map out who can benefit from which provision. ${ }^{47}$ Differentiation is also important for the delivery of technical assistance, without which developed countries have shown a tendency to commit largely to LDCs because they are deemed to have smaller shares in world trade. The lack of differentiating criteria has also lead developed countries to apply their own standards when selecting countries in extending assistance, which often times is politically motivated and non-transparent. ${ }^{48}$ Other elements such as transitional periods would also benefit from differentiation as it takes into account individual circumstances of developing countries. ${ }^{49}$

\section{The Rules on Flexibility}

At a glance it appears that the SDT provisions which provide developing countries with flexibilities, whether they are to increase trade opportunities, safeguard interests, exempt from commitments, allow transitional time periods, provide technical assistance, or established exclusively for LDCs, are quite clear cut. But if we are to look closer, we can see that they are formulated in a broad, non-prescriptive manner, leaving them wide open for interpretation in their implementation. The provisions lack a more specific guidance or mechanism on how they are to be implemented. This has been viewed as one of the factors why countries have a relatively informal approach to SDT.

In other words, it is not clear to distinguish from the provisions as to "who is entitled to get what, from whom, when, how and why?". ${ }^{50}$ Many of the SDT provisions across the agreements stipulate that special regard and attention is to be given to the situation of developing countries when applying certain measures or that member countries are to give preferences to the products of developing countries. As a rule, those provisions are clear in

\footnotetext{
${ }^{46}$ Manickan Supperamaniam "Special and Differential Treatment for Developing Countries in the WTO" in Gary P. Sampson and W. Bradnee eds Chambers Developing Countries and the WTO (United Nations University Press, Tokyo, 2008), at 137.

47 Jeffrey L. Dunoff "The Post-Doha Trade Agenda: Questions about Constituents, Competence, and Coherence" in Buckley, above n 1, at 59.

${ }^{48}$ Constantine Michalopoulos "Special and Differential Treatment: The Need for a Different Approach" in Gary P. Sampson and W. Bradnee Chambers eds Developing Countries and the WTO (United Nations University Press, Tokyo, 2008), at 123.

49 Manuela Tortora "Special and differential treatment and development issues in the multilateral trade negotiations: the skeleton in the closet" (2003) UNCTAD Draft Paper WEB/CDP/BKGD/16, at 4.

${ }^{50}$ Alavi, above n 22, at 17.
} 
that they create a binding obligation for member countries to consider and respect the needs of developing countries. These obligations instruct member countries to act in a certain manner, however, they do not "state precisely what constitutes the right forms of action and when they should be performed". ${ }^{51}$ The provisions use terms such as "shall consider", "when considering", or "shall explore", but without precise guidance on what those acts entail, their meaning becomes vague and may be interpreted as to require no action or mere consideration.

There is a tendency of using a flexible approach in interpreting the provisions by member countries. This flexibility has no doubt lead in part to the ineffectiveness of the provisions. Member countries may feel that they are only obligated to act as far as giving consideration to developing countries' needs without actually providing anything meaningful to facilitate their trade or assist their integration. Moreover, in the absence of a precise and comprehensive guideline on what steps to take, measures to implement, or assistance to provide, it may be challenging or burdensome for some member countries to establish the appropriate action. Additionally, the inclination to provide or not to provide tangible support cannot be pursued under the Dispute Settlement Mechanism (DSM).

It can be observed that while the issue of development enjoys strong political support in the WTO, it is not supported by a clear and precise legal structure, hence greatly limiting its value. ${ }^{52}$ This attitude towards development is also reflected in the number of dispute cases involving issues of development, which there are not many of. It has also been demonstrated that SDT provisions have not been successfully invoked under the DSM "because they have been too vague or because the judiciary has applied literal or contextual methods of interpretation which are traditional and 'safe'. ${ }^{3}$ This should come as no surprise as the Dispute Settlement Understanding (DSU) have been more "declarative rather than operative". ${ }^{54}$ Hoekman further states that even though the DSU gives "special attention to the particular problems and interests of developing countries during consultations", it does not provide an operative guideline. ${ }^{55}$

\footnotetext{
${ }^{51}$ Alavi, above $\mathrm{n} 22$, at 17.

52 Above n 22, at 23.

${ }^{53}$ Above $n$ 22, at 18 .

54 Bernard Hoekman "The WTO: Functions and Principles" in Bernard Hoekman, Aaditya Mattoo and Philip English eds Development, Trade, and the WTO: A Handbook (The World Bank, Washington, D.C., 2002), at 73.

55 Above $n$ 54, at 73 .
} 
In one of the cases involving SDT, EC-Antidumping Duties on Imports of CottonType Bed Linen ${ }^{56}$, India asserted that the EC in applying its measure had failed to consider India's situation as a developing country. India referred to Article 15 of the Anti-Dumping Agreement which states developed countries must give special regard to the special situation of developing countries and explore the possibilities of constructive remedies before applying anti-dumping duties. The Panel deciding the case viewed that the article "does not impose an obligation to actually provide any constructive remedy, but merely the obligation to consider the possibility of such remedy". ${ }^{57}$ The tendency is to decide a case strictly based on the treatment of products which can impair benefits to the country of origin, but not addressing whether that treatment has considered the special situations of the country of origin.

The same can be observed in the EC-Approval and Marketing of Biotech Products ${ }^{58}$ concerning a moratorium on the approval of biotech products from Argentina by the EC, which Argentina claimed to have significant impacts on its economic development. Argentina cited Article 10.1 of the Sanitary and Phytosanitary Agreement which states that the preparation and application of measures shall take into account the special needs of developing members and LDCs. In Argentina's view the EC is obligated to abide by that binding provision and in failure to do so had impaired its development. But the Panel in this case was of the view that the obligation requires member countries to merely consider the needs of developing countries and does not necessitate a positive action by the importing member. ${ }^{59}$

The Panels in US-Measures Affecting the Production and Sale of Clove Cigarettes ${ }^{60}$ and US-Certain Country of Origin Labelling (COOL) Requirements ${ }^{61}$ respectively reiterated the decision made in the EC-Biotech case with regard to the complainants' claim and stated that the United States had no explicit obligation to seek their views in the preparation and application of the measures in question. To the complainants' (Indonesia and Mexico) claim that the US had fail to take into account their special development needs under Article 12.3 of

${ }^{56}$ EC-Anti-dumping Duties on Imports of Cotton-Type Bed Linen WT/DS141/R, 30 October 2000 (Panel Report).

${ }^{57}$ Hoekman, above $\mathrm{n} 54$, at 74.

58 EC-Approval and Marketing of Biotech Products WT/DS291/R-WT/DS292/R-WT/DS293/R, 29 September 2006 (Panel Reports).

${ }_{59}$ Peter Van den Bossche and Werner Zdouc The Law and Policy of the World Trade Organization (Cambridge University Press, New York, 2013), at 939).

${ }^{60}$ United States-Measures Affecting the Production and Sale of Clove Cigarettes WT/DS406/R, 2 September 2011 (Panel Report).

${ }^{61}$ United States-Certain Country of Origin Labelling (COOL) Requirements WT/DS384/RW WT/DS386/RW, 20 October 2014 (Panel Report). 
the Technical Barriers to Trade (TBT) Agreement, the Panel viewed that the US is merely required to give active and meaningful consideration to such needs. These cases further exemplify the limited value that SDT provisions have for developing countries. ${ }^{62}$

\section{The Legal Status of Special and Differential Treatment}

As mentioned previously, the WTO agreements are a product of political compromise, that within the legally binding nature of its provisions it allows room for flexibility in its implementation. ${ }^{63}$ Seen from SDT point of view this fact can have both a positive and negative impact. It is positive in the sense that it affords special treatment to developing countries including to derogate from obligations or to modify commitments according to their development needs. On the other hand, it also comprises of obligations that require other member countries to act only as far as giving consideration to the special needs and situations of developing countries. As demonstrated in the previous section the latter is reflected in the formulation of provisions that decide whether they create an obligation or not. The difficulty in implementing SDT provisions is that many of them are formulated as bestendeavour clauses, soft-law or non-binding. ${ }^{64}$

The lax nature of the provisions translates into the obligation to do nothing because according to them there are no actions to undertake. The provisions do not require developed countries to alter or tailor their domestic policies to facilitate the special situations of developing countries, nor entail any other legal steps. ${ }^{65}$ So by merely affording flexibilities to developing countries, it is already considered as giving help or providing them with assistance, thereby relieving developed countries of their "responsibility to act in more essential areas". ${ }^{66}$ As such, the provisions which apply to developed countries are virtually non-enforceable under the DSU and would hardly confer meaningful benefits to developing countries. ${ }^{67}$

It can also be established that some of the SDT provisions are formulated in a vague manner. This may have been done to satisfy developing countries' need to feel that their aspirations are taken into account and reflected in the agreements, while at the same time

\footnotetext{
${ }^{62}$ Van den Bossche, above n 59, at 887.

${ }^{63}$ Alavi, above $\mathrm{n} 22$, at 4.

${ }^{64}$ Above $\mathrm{n} 22$, at 5 .

${ }^{65}$ Gary Sampson The WTO and Sustainable Development (United Nations University Press, Tokyo, 2005), at 197.

66 Above n 65 at 197.

${ }^{67}$ Above n 65, at 211.
} 
highlighting the role that developed countries can assume in facilitating those needs but without implicating excessive responsibility. It may also stem from the argument that allowing developing countries too much flexibility will undermine the system as a whole. Another factor may be that it was a compromise as part of the "single undertaking" where developing countries had to agree to all the agreements as a package and in exchange was willing to do so provided that their concerns are taken into account.

This weakness in the provisions has long been identified and became part of the motive why developing countries are striving for further legalization to make them more binding, mandatory, precise, and organized. But often times this has been met with opposition by developed countries, "who are not interested in committing themselves to binding promises without receiving anything in return". ${ }^{68}$ This is still very much the case today, which is why progress has been slow. Some of the arguments for strengthened provisions have been overtaken by events because it has taken this long to agree on them and many of the developing countries have overcome the need for the provisions which they sought for in the beginning. The notion of the developing country has shifted along with those changes, who now have other different interests to pursue, hence reducing the united support that SDT enjoyed at the beginning.

Being part of the negotiations one would feel that developing countries have become somewhat jaded by the discussion and growing tired in their effort to strengthen SDT. Many feel that SDT, because of its non-legal nature, does not serve to help them achieve their interests and turn their attention elsewhere. Often the voice of resistance can be heard louder in the negotiations than the voice of support. Often what disguises support is nothing more than normative and rhetorical expressions of the importance of SDT and its potential benefit to developing countries. The CTD-SS has come close to concluding its work many times but falls short each time because countries change their minds, their positions, their requests, or their proposals at the last minute. The same arguments have been repeated to a point of exhaustion that it puts member countries off from exerting genuine effort in the discussion.

Furthermore, the non-binding nature of the provisions translates to SDT being seen merely as an exception to obligations or the general rules, rather than a principle of the

\footnotetext{
${ }^{68}$ Alavi, above n 22, at 102.
} 
WTO. ${ }^{69}$ In implementing the provisions, the focus tend to be on the obligation to consider or simply take into account, instead of on the special status and needs of developing countries. This creates a certain unfairness that continues to separate countries into the developed and developing country groupings, where one is to give and the other is to receive regardless of the form of support. The provisions need to be attuned to the concept of fairness, which is about truly facilitating the participation of developing countries in international trade, to minimize costs, and create a level playing field. ${ }^{70}$

The effect of this problem, among others, is apparent in certain areas of negotiations. Because developing countries feel unsatisfied with the implementation of SDT and with the lack of development in negotiations, they have been impeding progress elsewhere in the negotiations, such as the Trade Facilitation Agreement that was agreed in 2013 but then experienced setback in 2014. This has also happened to the rest of the Singapore Issues (trade and investment, trade and competition policy, and transparency in government procurement) on which developing countries have refused to commence negotiations. It appears that sluggish process and lack of concessions will continue to pervade the Doha Round as long as developing countries feel dissatisfied with the treatment accorded to them.

\section{Relationship between the Dispute Settlement System and Special and Differential Treatment}

\section{A Special and Differential Treatment in the DSU}

The Uruguay Round introduced for the first time a strengthened dispute settlement system. Unique to the WTO, its dispute settlement system is deemed a pioneer in the expanse of international organizations. It is also the most effective mechanism as it comprises a judicial process used by member countries to seek justice in case of breach in the agreements. For developing countries, the system "allows for greater certainty in the implementation of decisions by panels and allows them to challenge more powerful developed countries". ${ }^{71}$ The strengthened system takes the form of SDT provisions in the DSU to facilitate developing countries' use of it. These provisions include extended panel duration, extended consultation periods, special attention to developing country problems and interests, indication in panel

\footnotetext{
${ }^{69}$ Andrew D. Mitchell "A legal principle of special and differential treatment for WTO disputes" WT Rev 5(3) 2006, at 445-469.

${ }^{70}$ Frank J. Garcia “Beyond Special and Differential Treatment”, 27 B.C. ICL. Rev. 291(27) 2004, at 299.

${ }^{71}$ Michalopoulos, above n 30, at 15.
} 
report with regard to SDT raised, allow panellists from developing countries, additional legal assistance, implementation of recommendations with respect to developing country interests, and special procedures for LDCs. Additionally, the WTO Secretariat is to conduct training courses for interested member countries to better enable them to use the system.

These changes were necessary as part of the effort to give developing countries a level playing field, and the number of developing countries using the system has been increasing steadily ever since. This trend demonstrates that the system has brought favourable changes to developing countries, although as time progressed they began to feel dissatisfied. This owes to the fact that many of the provisions "are worded merely as guidelines or suggestions, rather than obligations". ${ }^{72}$ Article 4.2 and 4.10 of the DSU require member countries to "accord sympathetic consideration" and "give special attention" to developing countries and their situations. Article 21.2 states that "particular attention should be paid" to matters affecting developing countries interests. Similarly, Article 24.1 regarding LDCs stipulates that "particular consideration shall be given" to the special situation of LDCs.

From another perspective, this supposedly strengthened system and its enforceability lead to the weakening of the informal SDT that developing countries utilize to seek exemptions, making their policies more susceptible to challenges by other member countries. ${ }^{73}$ But since invoking SDT provisions in the application of a measure being challenged has not been proven very successful, some are compelled to seek to legalize the SDT provisions further. Hence, developing countries request that the provisions be made obligatory instead of mere considerations. ${ }^{74}$ This way developed countries would legally have to adapt their measures to the special needs and interests of developing countries, while developing countries can securely adopt policies that are specifically tailored to those needs and interests.

\section{B Problems for Developing Countries}

Despite the statistics on the frequent use of the dispute settlement system by developing countries, they continue to face challenges with the DSU which cannot be solved by merely recognizing and extending them the rights to SDT available under the agreements.

\footnotetext{
${ }^{72}$ William Goldman "Developing Countries and the WTO: The Need for More Mediation in the DSU" 9 HNL Rev. 331, 2004, at 8.

${ }^{73}$ Page, above n 31, at 26.

${ }^{74}$ Above n 31, at 26.
} 
Instead, what they seek is real justice through findings and recommendations that fully reflect the WTO's intended development objectives. ${ }^{75}$ Furthermore, the problems have focused on three major disadvantages experienced by developing countries which include: (1) difficulties in enforcing panel decisions, particularly upon developed countries; (2) disparity in financial and legal resources and capacity between developed and developing countries, particularly LDCs and countries with no representatives in Geneva; and (3) panels' tendency to "overfocus on the strict and close interpretation of the agreements". ${ }^{76}$

With regard to enforcement, which has been addressed at length in the negotiations to amend the DSU, the problem may be attributed to the fact that the DSB lacks the mechanism to enforce upon an offending party the obligation to adjust or remove the measure which has been decided as inconsistent with WTO rules. ${ }^{77}$ There is also no mechanism to provide sanctions in case of failure to comply with rulings. The only alternative to enforce rulings is by allowing the complainant to apply retaliatory measures or seek compensation for the losses incurred after the reasonable period of time for implementing the recommendations has lapsed. However, retaliation is too difficult to implement in reality, because it involves the suspension of concessions in other sectors which can also harm the domestic market or importers of the complaining country. Compensation on the other hand has unfortunately been a much preferred method for settlement for offending parties who are unwilling to adjust or remove their incompliant measures. The complaining party may be compensated for its loss but the measure in question continue to compromise the effectiveness of the system and put other member countries at disadvantage.

For many developing countries and LDCs the high cost of litigation and lack of expertise are still a major problem impeding their effective participation in the dispute settlement system. ${ }^{78}$ The litigation process comprises a series of steps which require financial costs and expertise such as hiring an advocate where governments lack in-house lawyers, preparing arguments and submissions, attending consultations and litigations abroad (generally in Geneva), and adjusting measures if decided to be in violation of a provision. Alternatively, developing countries may seek assistance from the WTO Secretariat in preparing a case, however, with the relatively small size of the Secretariat and the high number of cases that need attending to, the quality of assistance may be inadequate. Despite

\footnotetext{
${ }^{75}$ Goldman, above n 72, at 8 .

${ }^{76}$ Above $\mathrm{n} 72$, at 9 .

${ }^{77}$ Above $\mathrm{n} 72$, at 9 .

${ }^{78}$ Above $\mathrm{n} 72$, at 10.
} 
the provisions to accord more favourable treatment to developing and especially to LDCs, the WTO has not been extending adequate legal assistance to them "for fear of appearing nonneutral in disputes", and neither has it "the discretion to refuse to consider disputes if they might damage development". ${ }^{79}$ Another alternative would be to seek the assistance of the Advisory Centre on WTO Law (ACWL) for the preparation or representation in disputes at much lower costs than hiring a private advocate. ${ }^{80}$ The ACWL charges governments based on their status and size, although for some small countries even this may be excessive.

Regarding panels' tendency to over-focus on the strict and close interpretation of the agreements, developing countries' concern is that such tendency hinders panels from examining disputes from a development perspective and to provide adequate consideration to development issues. ${ }^{81}$ While commitments are worded in legal, obligatory manner, the provisions on SDT are more of soft laws and so in deciding between the former and the latter, panels prefer to base their interpretation on the more precise and clear obligations. It is generally understood that the DSU provides legal certainty to WTO rules, however it should not overlook the real and serious constraints faced by developing countries, particularly when the DSU itself is equipped with provisions to enable developing countries' participation. ${ }^{82}$ In this regard, panels have much to prove that they are capable of substantially addressing development concerns and have the authority to interpret provisions beyond what is merely written.

\section{Interpretation of Provisions}

SDT provisions in the agreements, such as the Anti-Dumping Agreement and the Safeguards Agreements, are quite specific regarding the treatments that they provide to developing countries. ${ }^{83}$ The Agreement on Safeguards contains an MFN exception (Article 9.1) that restricts member countries from imposing safeguard measures on imports originating in developing countries. But the exception is subject to very prescriptive conditions, such as that the share of imports cannot exceed 3 percent and that not more than 9 percent of total imports are from countries with less than 3 percent shares collectively. ${ }^{84}$ This

\footnotetext{
${ }^{79}$ Peter Kleen and Sheila Page Special and Differential Treatment of Developing Countries in the World Trade Organization (Global Development Studies, London, 2005), at 18.

${ }^{80}$ Goldman, above $\mathrm{n} 72$, at 10 .

${ }^{81}$ Above $\mathrm{n}$ 72, at 10-11.

${ }^{82}$ Above $\mathrm{n} 72$, at 11.

${ }^{83}$ Mitchell, above n 69, at 23.

${ }^{84}$ Above n 69, at 23.
} 
type of SDT provision illustrates that even though an exception is available for developing countries, making it operational is not simple. Were a panel to interpret this exception, instead of focusing on the SDT aspect, it will focus more on the impact of the exception on the importing member country, because essentially the DSU is about ensuring that no country's benefit is impaired. ${ }^{85}$

Contrary to the nature of the exception above, the Anti-Dumping Agreement contains an SDT provision (Article 15) that is more non-binding by merely obligating member countries to give special regard to the special situation of developing countries. ${ }^{86}$ Based on this, panels would not impose on member countries to take positive actions because the "parameters are undefined" and do not consider it to be their task to interpret the provision further with regard to SDT. ${ }^{87}$ In general, the approach to interpreting SDT provisions has been cautious and often translated as the unwillingness of panels to go beyond their traditional outlook. Panels habitually refrain from interpreting something which is subject to inconclusive negotiation, however, they are equipped with the authority to seek information and solicit inputs from outside the WTO or the disputing parties, such as experts and relevant organizations. Panels are not limited to the agreements in their effort to attain a more global perspective on deciding a case so that it is possible for them to provide more focus to development.

\section{Reforming the DSU}

It has been encouraging to see that more and more developing countries are taking advantage of the dispute settlement system, gaining expertise at it and utilizing it successfully. But the fact remains that many small countries, in particular LDCs, still require assistance to effectively use the system. ${ }^{88}$ The WTO Secretariat will need to play a more active role in assisting developing countries without fear of appearing non-neutral as the provision in the DSU that pertains to such a role is an SDT. It precisely means that the Secretariat must give favourable treatment to developing countries because their status entitles them to it under the DSU. The same needs to be applied to the rest of the SDT in the DSU although it may be more complex because they are vaguely worded and lack precision. It would send a positive signal and provide a model for implementation in the other

\footnotetext{
${ }^{85}$ Mitchell, above n 69, at 23.

${ }^{86}$ Above $\mathrm{n} 69$, at 24.

${ }^{87}$ Above n 69, at 24.

${ }^{88}$ Kleen, above n 79, at 58.
} 
agreements if this improvement takes place in the DSU, the tool that is supposed ensure enforcement.

Other areas that form part of developing countries' proposal for improvement correspond to the three main problems mentioned in the previous sub-section, which are enforcement, lack of resource, and development consideration. ${ }^{89}$ With regard to enforcement, one of the prominent proposals is that monetary compensation by developed to developing countries should be continuously paid until the violating measure is effectively removed because of the far reaching impact it may have on development. ${ }^{90}$ At the time being, the amount of compensation is agreed between the complainant and the respondent based on the calculated loss incurred from the time the measure is applied until approximately the time of litigation. The proposal seems to make much sense since a lot of developing countries are having or have had difficulties demanding enforcement in a number of disputes they have won against developed countries. Such can be seen in the EC-Bananas III (1998), US-Offset Act (Byrd Amendment) (2003), US-Upland Cotton (2008)91, US-Clove Cigarettes (2012), and US-Shrimp (2011). It is also a more realistic approach compared to pursuing retaliatory steps since the latter is much more complicated to implement. The problem often times is that compensation, being limited to a timeframe and amount, is used to maintain certain measures that are non-compliant. Consequently it has been misused to pacify complainants from further demanding adjustment of non-compliant measures, which undermines the system and adherence to the rules.

With regard to lack of resources, many of the problems experienced by developing countries stem for their lack of expertise, whether in understanding the agreements and/or using the dispute settlement system effectively. ${ }^{92}$ Article 27.2 and 27.3 instructs the WTO Secretariat to provide developing country members with technical assistance such as training courses to enhance their capacity in understanding and using the system. The Secretariat however has a limited number of experts who can divide their time between providing assistance in dispute cases at the WTO Geneva headquarters and conducting trainings/workshops abroad. Training sessions are often too short to be effective and also depend on the level of prior knowledge of the participants regarding the system. Often time

\footnotetext{
${ }^{89}$ Goldman, above n 72, at 12 .

${ }^{90}$ Above $\mathrm{n} 72$, at 12.

${ }^{91}$ Van den Bossche, above n 59, 199.

92 Goldman, above n 72, at 12.
} 
participants are not officials or professionals who deal with legal or trade issues so they neither have use of the knowledge nor put it to practice.

As a consequence it has been somewhat a challenge to evaluate whether the training courses have been effective. Improvements may have to include a better management of the training programs and the possibility of hiring experts from outside the WTO to conduct these courses. By hiring additional experts, duration of the courses can be extended, as well as to increase the number of courses. They may also assist in the designing of programmes to be more tailored to the needs and capacity of the relevant developing countries. The same may also be useful for assisting developing countries in the preparation of cases and alleviating them of some of the costs in making submissions and conducting litigation. ${ }^{93}$

Lastly, the most significant improvement that needs to be adopted is with regard to the lack of development consideration in the interpretation of agreements. ${ }^{94}$ It will have to entail changing the non-binding provisions into binding ones, changing the words "should" into "shall" 95 and requiring proof that consideration had really been taken. For example, this could be useful to effectively implement Article 12.11 DSU, which requires that panels "explicitly indicate the form in which account has been taken of relevant provisions on differential and more-favourable treatment for developing country Members that form part of the covered agreements have been raised by the developing country Member in the course of the dispute settlement procedures".

\section{Making Special and Differential Treatment More Effective, Precise, and Operational}

Improving SDT should not be regarded as optional, but as a necessity. Not only is it necessary to alleviate the disparity between member countries, but also to balance out competition between developed and developing countries. It is crucial for the viability of the WTO as an organization that proclaims itself as a development-promoting institution and which has dedicated a special round to improving development aspects of its trade rules. The ineffectiveness of the current SDT and the slow progress in improving it has far-reaching consequences on the credibility of the system as a whole and its ability to provide effective and enforceable rules to level out inequalities between member countries. If the Doha Round

\footnotetext{
93 Goldman, above, 72, at 12 .

${ }^{94}$ Above, 72, at 13 .

95 Above, 72, at 13.
} 
is to survive, or if it were to attain any meaningful result, the WTO and its member countries may have to rethink their approach to the negotiations. This would not only include adopting the changes which have been proposed for so long but to also reassess the "single undertaking" principle. Member countries may need to devise new mechanisms to salvage what agreements have been achieved and disregard those that cannot be without compromising the entire system. The Round is believed to have reached that critical point where things need to change drastically or risk a potential collapse.

As a start, since developing countries have different characteristics, capacity, and interests, SDT should not be made general. There must be an appropriate balance between flexibility and the principle of non-discrimination. This means that not all developing countries should be entitled to the same flexibility. Differentiation according to development level and needs must be applied in providing more favourable treatments to developing countries. There are several methods which can be applied to achieve this. Since developing country status is self-proclaimed and with general standards, it would be useful for the WTO to set new standards that would allow for differentiation among them. This could be done for example by separating them into groups according to their per capita income and/or share of world trade, the amount of financial flows or assistance already received for development, and creating specific flexibilities for different groups of developing countries for each agreement. ${ }^{96}$

Consequently, the challenge will be in attempting to create a balance between recognizing SDT as an inherent right to developing countries and then only allowing it to those that actually need it. It must be admitted that a number of developing countries do not wish to lose their status or have it reduced as a result of having advanced their development, since it allows them to maintain policies that would otherwise be discriminative or gives them a competitive advantage. But this is precisely the reason why developing countries need to be differentiated. Furthermore, for some developing countries the current SDT is no longer adequate or applicable, either because internal or external situations have changed and made it obsolete, or because they are sufficiently advanced that they no longer have a need for it. It would be important to get all developing countries to align their views on this matter so that they are not divided in their approach to achieve an improved SDT.

\footnotetext{
${ }^{96}$ Michalopoulos, above n 48, at 122.
} 
Having said that, the definition of development needs to be clarified and made more precise. As discussed in Chapter 2, the lack of a clear definition on development in the WTO has made the notion too wide-ranging and difficult for countries with different interests to have a common view on how to attain it. Hence, proposals on SDT have been quite diverse, rendering them difficult to agree on or garner sufficient support. The classic interpretation of development still applies but needs to be elaborated based on the link between trade and development. In the context of WTO it may have to include the different levels of development, such as those that correspond to the characteristics of LDCs, emerging economies, or middle-income countries. The concept of development could be made precise by specifying the indicators or parameters to render a country as having achieved a sufficient level of development, such as the presence of infrastructures, GDP, or trade index.

If member countries have a standard guideline on definition of development, it would be less complicated to distinguish the different groups of developing countries and in turn would simplify the process of deciding who is entitled to which SDT. Simultaneously, member countries will need to further strengthen the provisions by making them binding, awarding them legal status and thus rendering them as obligatory commitments. Some of the wordings that have lead to the flexible interpretation needs to be altered using binding terms and made more precise. Precision involves elaborating the specific treatments to be afforded to developing countries. For example if the provisions instruct member countries to "give consideration" or "take into account", they need to explain in detail what steps or measures that would entail.

The provisions need to be reinforced with specific actions that must be implemented by member countries when considering the special needs of developing countries, thus making them less vague and easier to implement. Such actions can range from doing a survey or study on the impact of measures on particular developing countries, consulting the relevant developing countries, or providing assistance before the application of measures that could potentially impair benefit. The strengthening of the provisions will need to be supported by improvement of the DSU, so negotiations in the two committees will have to be coordinated. Coherence between the agreements will need to be re-evaluated to ensure that they are in conformance and do not negate one another. If the DSU contains strong provisions that can induce enforcement with regard to commitments in the other agreements, perhaps the number 
of incompliance can be reduced, or if not at least the implementation of panel recommendations would be strictly adhered to.

Another approach to differentiating developing countries is by using graduation method. The graduation concept has been known since the GATT era and involves increased participation of developing countries based on their improved economic status and compliance with commitments. ${ }^{97}$ Member countries can opt to decide for themselves whether they have graduated on to a higher level of developing or developed status, or it can be monitored by the WTO Secretariat based on their trade indicators. In accordance with such concept in the GATT, member countries who have graduated shall be compelled to participate on a more equal footing in the system and no longer be eligible for flexibilities. They shall be bound to commitments as their developed partners and provide consideration to other developing countries in applying measures. Where applicable, they shall provide assistance to other developing countries who are less developed. If graduation is to be applied, then member countries have to agree on the indicators that will be used, which for graduating onto developed country status would have to be higher than those employed to differentiate developing countries.

Although the Doha Round is essentially about development, and that negotiations were initiated to improve the development dimensions of the agreements, the sense is that SDT does not assume a priority on the list of negotiating issues. Proposals for amendments on the SDT provisions have been submitted since the beginning of the Round and to date have been discussed extensively and altered numerously. Some of the proposals which have been agreed to, such as the 28 ASP, have to date not been adopted and have not formed a part of the relevant agreements. The reason for this is that member countries continue to revisit and revert back to already-agreed proposals making them vulnerable to further arguments and alterations. The same can also be said for proposals which intend to add new provisions or new elements to improve the precision of certain provisions, such as the Special Safeguard Mechanism in the Agriculture Agreement, disclosure requirement in the TRIPS Agreement, or exceptions for developing countries in the SPS Agreement.

With regard to the proposals which have already been agreed to, member countries should seriously consider adopting them by the next Ministerial Meeting which will take place in 2015 , even if they cannot agree on other issues. This may be an exception to the

\footnotetext{
${ }^{97}$ Alavi, above n 22, at 93.
} 
principle of single undertaking but it may be the only alternative to salvage what they can from the entire round of negotiations. The public, and to a certain extent the member countries, are beginning to lose confidence in the system. The fact that it has taken the WTO this long to strengthen its development dimension gives the impression that there is limited gain for developing countries and that it is not a fair system. The single undertaking may have served the organization well when it was first designed to attain agreement on all the agreements simultaneously, but it has somewhat complicated the adoption of decisions in the current Round. Even where a new agreement has been adopted (the Trade Facilitation Agreement) member countries can still backtrack from implementation due to disagreement in other areas of negotiations. The exception to the single undertaking principle is not to disregard it entirely or to undermine the system but to provide an impetus for agreement elsewhere in the negotiations and to restore confidence in the system. 


\section{Conclusion}

The SDT of WTO has gone through major changes over the past, more notably in the Uruguay Round, which resulted in the many provisions across the WTO agreements to give special rights to developing countries in the form of special treatments and flexibilities. As such the new SDT can be considered an achievement in the effort to integrate developing countries into the multilateral trading system. The reality however is that SDT has not been as beneficial as expected due to its legal character and formulation. It has not been effective in advancing the interests of developing countries due to issues such as interpretation, nonbinding provisions, and the lack of implementing procedures. Other factors such as the concept of development, dynamics of negotiations, and the absence of modalities to differentiate developing countries also resulted in the lack of focus of SDT. SDT also lacks the mechanism to make it more targeted, to serve the developing countries that are most at disadvantage. The DSU and interpretation of the provisions in dispute cases have not helped in clarifying the purpose and function of SDT, nor has it made the provisions more precise, effective, or operational. If SDT is to serve its purpose, the negotiations must employ a different approach in order to finally conclude an agreement. Besides addressing the challenges and factors that have weakened the utilization of SDT and made it ineffective, member countries would have to seriously reconsider their interests and positions to see whether it could truly improve SDT or only weaken it, possibly abandon issues that are impossible to agree on, and to agree on what they can without compromising the core purpose of SDT. 


\section{BIBLIOGRAPHY}

\section{PRIMARY SOURCES}

\section{A Cases}

EC-Anti-dumping Duties on Imports of Cotton-Type Bed Linen WT/DS141/R, 30 October 2000 (Panel Report).

EC-Conditions for the Granting of Tariff Preferences to Developing Countries, WT/DS246/AB/R, 7 April 2004 (Appellate Body Report).

EC-Approval and Marketing of Biotech Products WT/DS291/R-WT/DS292/R-WT/DS293/R, 29 September 2006 (Panel Reports).

United States-Measures Affecting the Production and Sale of Clove Cigarettes WT/DS406/R, 2 September 2011 (Panel Report).

United States-Certain Country of Origin Labelling (COOL) Requirements WT/DS384/RW WT/DS386/RW, 20 October 2014 (Panel Report).

\section{B Treaties}

Marrakesh Agreement Establishing the World Trade Organization (signed 15 April 1994, entered into force 1 January 1995).

General Agreement on Tariffs and Trade 1994 LT/UR/A-1A/1/GATT/1 (signed 15 April 1994, entered into force 1 January 1995).

\section{Reports}

Committee on Trade and Development "Note on the meeting of 25 March 2014" (2014) $\mathrm{TN} / \mathrm{CTD} / \mathrm{M} / 48$

\section{SECONDARY RESOURCES}

\section{A Texts}

Amin Alavi Legalization of Development in the WTO: Between Law and Politics (Kluwer Law International, Alphen aan den Rijn, 2009).

Andrew L. Stoler, Jim Redden and Lee Ann Jackson eds Trade and Poverty Reduction in the Asia-Pacific Region: Case studies and lessons from low-income communities (Cambridge University Press, New York, 2009). 
Basudeb Guha-Khasobis ed The WTO, Developing Countries and the Doha Development Agenda: Prospects and Challenges for Trade-Led Growth (Palgrave Macmillan, New York, 2004).

Bernard Hoekman, Aaditya Mattoo and Philip English eds Development, Trade, and the WTO: A Handbook (The World Bank, Washington, D.C., 2002).

Constantine Michalopoulos "The role of special and differential treatment for developing countries in GATT and the World Trade Organization" (1999) World Bank Policy Research Working Paper.

Dencho Georgiev and Kim Van der Borght eds Reform and Development of the WTO Dispute Settlement System (Cameron May, London, 2006).

Edwini Kessie "The Legal Status of Special and Differential Treatment" in WTO Law and Developing Countries (Cambridge University Press, New York, 2007).

Gary Sampson The WTO and Sustainable Development (United Nations University Press, Tokyo, 2005

Gary P. Sampson and W. Bradnee eds Chambers Developing Countries and the WTO (United Nations University Press, Tokyo, 2008).

Geerd A. Zonnekeyn Direct Effect of WTO Law (Cameron May, London, 2008).

George A. Bergman and Petros C. Mavroidis eds WTO Law and Developing Countries (Cambridge University Press, New York, 2007).

Jeremy Streatfeild and Simon Lacey eds New Reflections on International Trade: Essays on Agriculture, WTO Accession and Systemic Issues (Cameron May, London, 2008).

Peter Kleen and Sheila Page Special and Differential Treatment of Developing Countries in the World Trade Organization (Global Development Studies, London, 2005)

Manuela Tortora "Special and differential treatment and development issues in the multilateral trade negotiations: the skeleton in the closet" (2003) UNCTAD Draft Paper $\mathrm{WEB} / \mathrm{CDP} / \mathrm{BKGD} / 16$.

Markus W. Gehring and Marie-Claire Cordonier Segger Sustainable Development in World Trade Law (Kluwer Law International, Alphen aan den Rijn, 2005).

Mitsuo Matsushita, Thomas J. Schoenbaum and Petros C. Mavroidis The World Trade Organization: Law, Practice, and Policy (Oxford University Press, New York, 2006).

Peter Van den Bossche and Werner Zdouc The Law and Policy of the World Trade Organization (Cambridge University Press, New York, 2013).

Ross P. Buckley ed The WTO and the Doha Round: The Changing Face of World Trade (Kluwer Law International, The Hague, 2003). 
Sheila Page "The Evolution of Special and Differential Treatment in the Multilateral Trading System” (2004) International Centre for Trade and Sustainable Development.

Sheila Page and Peter Kleen Special and Differential Treatment of Developing Countries in the World Trade Organizations (Overseas Development Institute, London, 2005).

Spencer Henson and John S. Wilson The WTO and Technical Barriers to Trade (E. Elgar, UK, 2005).

Thomas W. Hertel and L. Alan Winters eds. Poverty and the WTO: Impacts of the Doha Development Agenda (IBRD/The World Bank, Washington DC, 2005).

WTO Secretariat The WTO Dispute Settlement Procedures (Cambridge University Press, Cambridge, 2003).

WTO Secretariat The Legal Texts, The Results of the Uruguay Round of Multilateral Negotiations (Cambridge University Press, New York, 1999).

\section{B Articles}

Akiko Yanai "Rethinking Special and Differential Treatment in the WTO" (2013) IDE Discussion Paper 435.

Andrew D. Mitchell "A legal principle of special and differential treatment for WTO disputes" [2006] WT Rev 5(03).

E. Moïsé "Special and Differential Treatment in the Area of Trade Facilitation" (2006) OECD Trade Policy Papers 32.

Frank J. Garcia "Beyond Special and Differential Treatment" [2004] 27 B.C. ICL. Rev. 291(27).

Maureen Irish "Special and Differential Treatment, Trade and Sustainable Development" (2010) Law and Development Institute.

William Goldman "Developing Countries and the WTO: The Need for More Mediation in the DSU” [2004] 9 HNL Rev. 331.

\section{Internet Resources}

John Whalley "Special and Differential Treatment in the Millennium Round" (1999) CSGR Working Paper No. 30/99<www.dspace.africaportal.org>.

Norma Breda dos Santos, Roge Ârio Farias and Raphael Cunha "Generalized System of Preferences in General Agreement on Tariffs and Trade/World Trade Organization: History and Current Issues" (2005) Journal of World Trade 39(4) <www.academia.edu>.

Thomas Fritz "Special and Differential Treatment for Developing Countries" (2005) Global Issues Paper No. $18<$ www.thomas-fritz.org>. 
Improving the Effectiveness of the Special and Differential Treatment of the World Trade Organization

WTO Secretariat "Special and differential treatment provisions" < www.wto.org $>$.

WTO Secretariat "Cancún WTO Ministerial 2003: Briefing Notes on Special and Differential Treatment: Grappling with 88 proposals" <www.wto.org>. 